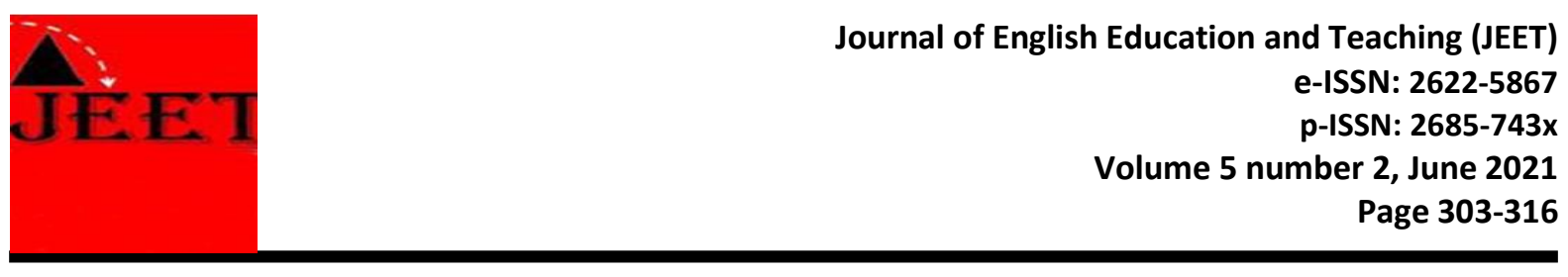

\title{
Teacher Talk in English Foreign Language Classroom
}

\author{
Reka Solita \\ English Education Study Program of Universitas Bengkulu \\ rekhasolita@gmail.com \\ Alamsyah Harahap \\ English Education Study Program of Universitas Bengkulu \\ alamsyahharahap18@yahoo.com \\ Azhar Aziz Lubis \\ English Education Study Program of Universitas Bengkulu \\ azharlubis@unib.ac.id
}

Corresponding email: rekhasolita@gmail.com

\begin{abstract}
This research investigates teacher talk in SMAN 5 Kota Bengkulu, based on FLINT theory by Moskowitz (1971). This research analyzed teacher talk categories spoken and the high frequency teacher talk used by the teacher to see what the category was often used in classroom. The design of this research was descriptive mixed-method. The subject of the research was two teachers who are teaching English class in tenth-grade at SMAN 5 Bengkulu academic years 2019/2020. There were two teachers, male and female taught in tenth grade in this school. The teachers had teaching experience for more than five years and certified as school teachers. In this research, the researcher focused on teacher talk in classroom interaction in the English class. The data of this study were taken by video recording the teacher-students interaction in the classroom that contained eleven categories of teacher talk. The data of this research were analyzed qualitatively and quantitatively. The result of this study that all of teacher's talk categories often used by the teacher who taught at tenth-grade of SMAN 5 Kota Bengkulu during classroom interaction. The high frequency of teacher talk categories was asking question around $55.6 \%$, while the least of teacher talk categories were correcting without rejection and criticizes student behavior. It means that the teachers tended to use indirect influence rather than direct influence.
\end{abstract}

Keywords: Teachers talk, Types of teacher talk, foreign language interaction (FLINT).

\section{Introduction}

Teacher talk is giving direction, explaining learning activities, confirming student's understanding to identify the parts of teacher talk that arises during learning activities. In the use of English the teacher interacts with students using the mix language, therefore students become easy to understand and also follow what is conveyed by the teacher. When the class becomes relevant and then the parts of teacher talk can 
be used by the teacher to increase students' activity, interact with students, and there is feedback between the teacher and students in the teaching and learning.

Teacher talk refers to talk the teacher says to learners in the second language learning classroom. EFL classroom teaching is different from other classroom teaching (Walsh, 2002 cited in Wang, 2014). In EFL classroom, language is not only the objective of learning but the medium of teaching. Thus, the proper use of teacher talk will have positive or negative effect on language learners' language output.

Talk is needed by teacher and students in order to be able to exchange any ideas they possess. For students, teacher talk is considered important in the classroom. Through teacher talk, students are possible to obtained new knowledge any information they needed to learn a lesson. They could be encouraged in giving their ideas about the lessons or concepts being delivered by teacher. In learning a language, especially foreign language, exposure to the language they were learning is highly needed in the classroom and it can be attained through teacher's talk.

Related to the mention need of exposure, teacher talk is remarkable input in English as foreign class for students who are learning English (Gebhard, 2006 cited in Putri, 2015). In addition, in English class as a foreign language has been found that teacher talk dominated the interaction (Ogunleye, 2009; Nurmasithah, 2010; and Putri, 2015). Teacher talk in the classroom should not only be seen from its dominance. In line with this, Gharbavi and Iravani (2014) stated that teacher talk should be able to offer opportunities to participate more in the classroom and encourage students to interact with the teacher or other students. Furthermore, teacher talk is also to influence the characteristics of interaction that is occurring in the classroom between teacher and students.

In Indonesia, teacher speech was a social phenomenon because most English teachers were multilingual and non-native speakers of English. Consequently, most the teachers used two or more languages in their teaching and learning process, as well as classes and English teachers not only as a medium for acquiring new languages, but also as objects of learning. English teachers and most second language classes used language as a medium and object of learning through language teaching as the message. (Long \& Sato cited in Harahap \& Emzir, 2015; Harahap \& Emzir, 2015).

However, interaction in the language classroom was very complicated. Many problems appeared to develop the teaching and learning process through communicative interaction because students had difficulty in expressing themselves in 
using English that was not their mother tongue. Therefore, the way a teacher used language and provided opportunities for students to develop language was very important to understand. In other words, the teacher talks aimed at building and maintaining good communicative practices in the complex series discourse, took a large portion of the class. Therefore, through investigating interaction in the classroom, teachers would be able to develop their awareness to apply teacher's conversations that are appropriate in teaching.

Teacher talk is any word or sentence spoken by the teacher during interaction in teaching and learning process. It is happening when the teacher given an explanation, ask questions, gives feedback, etc. Teacher talk was crucial and important, not only for the organization and for management of the classroom but also the process of acquisition. In teaching process, the teacher often simplify the speech, giving it many of the characteristic of foreign talk such as applying slower and louder than normal speech, using simpler grammar and vocabulary, and topics are sometimes repeated.

In line with the background above, this research investigates teacher talk categories used based on FLINT theory and the high frequent teacher talk used by the teacher to seen what the category was often used in classroom. FLINT is the simplest one to be method of this research. As long as the teacher talk in all school grades, it was also very important to do in SMA especially in SMA Negeri 5 kota Bengkulu which as one of the best schools in Bengkulu and is a national standard which must prepare their students have strengths skills of English. Furthermore, some students were sleepy and others had little participant in the classroom interaction. One of the factors could be the ways of the teacher asking questions to students, when teacher used the question to check the students' understanding or confirm that the students were paying attention to the lesson, the students would only simple answer.

It is one of the reasons why the researcher takes this topic. There were 2 main questions in this research 1) what are the teacher talk categories spoken in the classroom interaction at the tenth grade of SMAN 5 Bengkulu based on Foreign Language Interaction (FLINT) analysis system? 2) What is the high frequent teacher talk used in the classroom interaction as effect of teacher talk categories? 


\section{Research Methodology,}

This research used descriptive mixed method that started from gathering the data until reporting the results of research Descriptive qualitative research was defined as a design to obtain information about the current status of phenomena and to determine natural situation as they exist during the study. Kumpulainen (2009) states classroom interaction is suitable as the observation that is for categorizing into which relevant talk. Moreover, quantitative research design is categorized in this research, because the researcher collected the data in form of numerical and percentage in order to found the high frequent of teacher talk used by the teacher in classroom interaction.

The subject of the research was two teachers who are teaching English class in tenth-grade at SMAN 5 Bengkulu academic years 2019/2020. There were two teachers, male and female taught in tenth grade in this school. The teachers had teaching experience for more than five years and certified as school teachers. In this research, the researcher focused on teacher talk in classroom interaction in the English class.

In this research only used video recording for collecting the data, the researcher recorded the whole part of the teaching learning process. They were teachers and students in tenth grade of SMAN 5 Kota Bengkulu. The researcher recorded the lesson in classroom four times on four meetings. Each meeting consisted of 2 hours effective learning time ( $2 \times 45$ minutes).

\section{Findings and Discussion,}

\section{Findings}

There were two research questions of this study. The first was the type of Teacher Talk categories spoken by the teacher during classroom interaction based on FLINT theory. The second question was the high frequency of teacher talk used by the teacher during classroom interaction based on FLINT theory. The detailed results of each research questions as following;

\section{Type of Teacher Talk Categories Spoken By The Teacher During Classroom Interaction Based on FLINT Theory}

There were eleven categories of teacher talk used by the teacher who taught in tenth-grade at SMA Negeri 5 Kota Bengkulu based on FLINT theory. After analyzing the data, the results are presented in the chart below; 
Chart 1. Results of the FLINT's Teacher Talk Categories for All Meetings

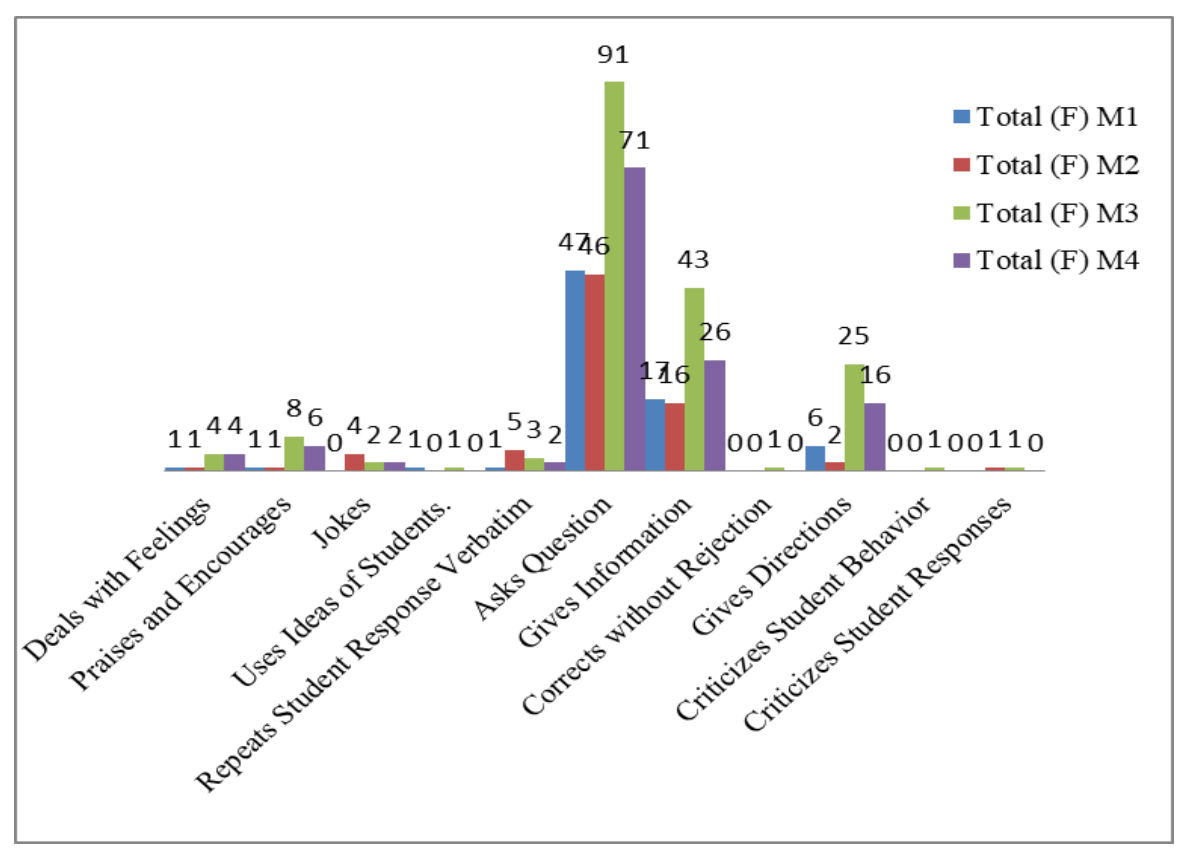

As presented in chart 1 , the result of teacher talk categories used in classroom interaction at tenth grade, both the teachers who taught in the class were using FLINT theory for four meetings. It could be seen that the results of the teacher talk categories were often used by both teachers in interacting with their students. Each teacher has a category of teacher talk that was often used, the similarities from the teacher talk category that were often used by both teachers Teacher A and Teacher B, asking questions in the first place, giving information in the second place, and giving direction in the third place.

\section{The high frequency of teacher talk used by the teacher during classroom interaction based on FLINT theory}

This section provides the high frequency of teacher talk used by the teacher during classroom interaction based on FLINT theory in the 2019-2020 academic years. The results are illustrated in the chart below;

Chart 2. The Highest of FLINT's Teacher Talk Categories for All Meetings 


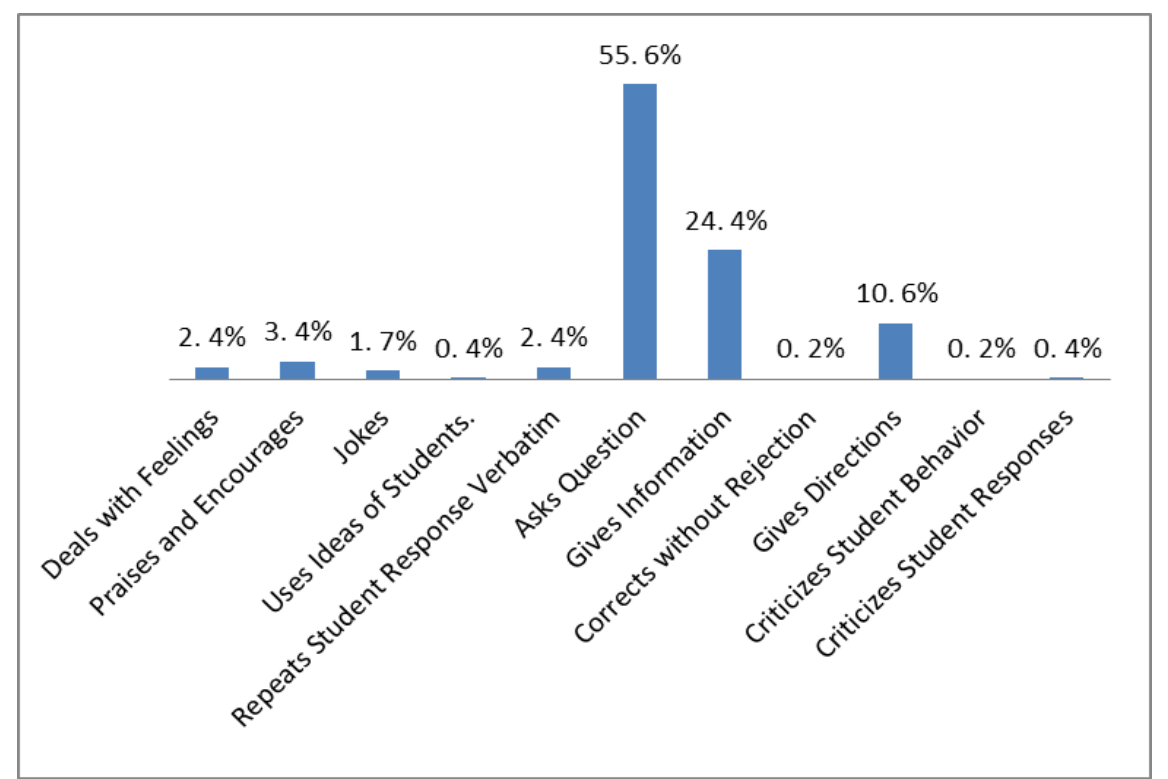

As presented in Chart 2, it shows that the high frequency of teacher talk used in classroom interaction of teaching learning process from $1^{\text {st }}$ until $4^{\text {th }}$ meeting showing was asking question. In detail researcher had calculated teacher talk used by the teacher in classroom interaction at each meeting in the following table;

Table 1. FLINT's Teacher Talk Analysis at the $1^{\text {stuntil }} 4^{\text {th }}$ meeting

\begin{tabular}{|c|c|c|c|c|c|}
\hline \multirow[t]{2}{*}{$\mathrm{No}$} & \multirow[t]{2}{*}{ Category } & \multicolumn{4}{|c|}{ Remark } \\
\hline & & Meeting 1 & Meeting 2 & Meeting 3 & Meeting 4 \\
\hline 1. & $\begin{array}{l}\text { Deals with } \\
\text { Feelings }\end{array}$ & $\begin{array}{l}\text { Oke, before w } \\
\text { start the study } \\
\text { Who's alfa? ... (2) }\end{array}$ & $\begin{array}{l}\text { eSo for today we are } \\
\text { y.let's talk about } \\
\text { present... (1) }\end{array}$ & $\begin{array}{l}\text { Hello, are you } \\
\text { ready for class? So, } \\
\text { make sure you are } \\
\text { focus on class } \\
\text { today? (4) }\end{array}$ & $\begin{array}{l}\text {.... to see you } \\
\text { again. I hope you } \\
\text { are fine today. Are } \\
\text { you oke? (4) }\end{array}$ \\
\hline 2. & $\begin{array}{l}\text { Praises and } \\
\text { Encourages }\end{array}$ & $\begin{array}{l}\text { Simple past, very } \\
\text { good. (1) }\end{array}$ & You are right (1) & $\begin{array}{l}\text { I understand that, } \\
\text { now I understand, } \\
\text { I var biasa Nabil. (8) }\end{array}$ & Alright good. (6) \\
\hline 3. & Jokes & - & $\begin{array}{l}\text { Karna saya depan } \\
\text { pintu ya. } \\
\text { (laughing) (4) }\end{array}$ & $\begin{array}{l}\text { If you supervised in } \\
\text { your mind, } \\
\text { forgetting for her. } \\
\text { (2) }\end{array}$ & $\begin{array}{l}\text { Kalo Bahasa } \\
\text { Indonesia you say } \\
\text { we-we-wean ya } \\
\text { we-we-we } \\
\text { (laughing) (2) }\end{array}$ \\
\hline
\end{tabular}




\begin{tabular}{|c|c|c|c|c|c|}
\hline 4. & $\begin{array}{l}\text { Uses Ideas of } \\
\text { Students. }\end{array}$ & $\begin{array}{l}\text { Tadi sudah dibilang } \\
\text { kiky ya "Mam, } \\
\text { perbuatan itu } \\
\text { sudah sekarang } \\
\text { masih } \\
\text { berlangsung" ok, } \\
\text { sekarang masih } \\
\text { berlangsung. (1) }\end{array}$ & 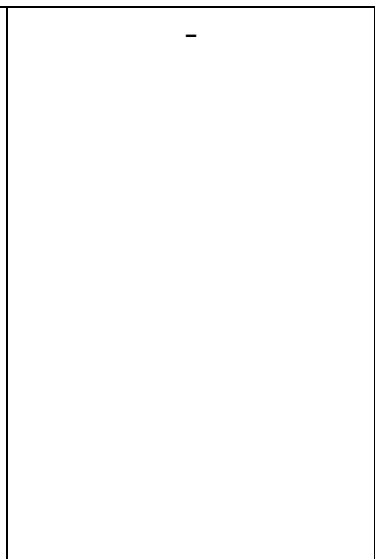 & $\begin{array}{l}\text { Ok, Orientation } \\
\text { and event. (1) }\end{array}$ & - \\
\hline 5. & $\begin{array}{l}\text { Repeats } \\
\text { Student } \\
\text { Response } \\
\text { Verbatim }\end{array}$ & $\begin{array}{l}\text { Have eaten, terus. } \\
\text { Jadi, ini adalah the } \\
\text { stuff of present } \\
\text { perfect tense. (1) }\end{array}$ & Have (5) & $\begin{array}{l}\text { Ok, to inform ya. } \\
\text { (3) }\end{array}$ & $\begin{array}{l}\text { TV, brochure, } \\
\text { entertain. (2) }\end{array}$ \\
\hline 6. & Asks Question & $\begin{array}{l}\text { What about } \\
\text { exercise? (47) }\end{array}$ & $\begin{array}{l}\text { How many types is } \\
\text { present perfect? } \\
(46)\end{array}$ & $\begin{array}{l}\text { Roro, what is the } \\
\text { purpose recount } \\
\text { text? (91) }\end{array}$ & $\begin{array}{l}\text { So let start our } \\
\text { class, so last week } \\
\text { we discuss about? } \\
\text { (71) }\end{array}$ \\
\hline 7. & $\begin{array}{c}\text { Gives } \\
\text { Information }\end{array}$ & $\begin{array}{l}\text { Ok, today. We go } \\
\text { on to the next, we } \\
\text { have discusses } \\
\text { about simple past. } \\
\text { So today we will } \\
\text { discuss about } \\
\text { present perfect. } \\
\text { (17) }\end{array}$ & $\begin{array}{l}\text { "I have eaten in } \\
\text { that restaurant } \\
\text { many times" so this } \\
\text { is example of } \\
\text { present perfect } \\
\text { tense. (16) }\end{array}$ & $\begin{array}{l}\text { Right, so I always } \\
\text { told you every text } \\
\text { as is purpose. So } \\
\text { you are reading to } \\
\text { focus on first word. } \\
\text { If you started that } \\
\text { purpose to } \\
\text { entertain to a } \\
\text { view, right. (43) }\end{array}$ & $\begin{array}{l}\text { So today, we are } \\
\text { going to study new } \\
\text { topic and it is good } \\
\text { topic for discuss, it } \\
\text { is about } \\
\text { advertaisment. (26) }\end{array}$ \\
\hline 8. & $\begin{array}{l}\text { Corrects } \\
\text { without } \\
\text { Rejection }\end{array}$ & - & - & $\begin{array}{l}\text { Italian. Italian is } \\
\text { that you was } \\
\text { pronounce is from } \\
\text { Itce.. Itcelien not } \\
\text { ita..lian. (1) }\end{array}$ & - \\
\hline 9. & $\begin{array}{c}\text { Gives } \\
\text { Directions }\end{array}$ & $\begin{array}{l}\text { Coba kita lihat, } \\
\text { number one! Yes } \\
\text { Rahman. (6) }\end{array}$ & Ingat! (2) & $\begin{array}{l}\text { Please don'† } \\
\text { forget it, ok. (25) }\end{array}$ & $\begin{array}{l}\text { You can open your } \\
\text { textbook! (16) }\end{array}$ \\
\hline
\end{tabular}




\begin{tabular}{|c|c|c|c|l|c|}
\hline 10. & $\begin{array}{c}\text { Criticizes } \\
\text { Student } \\
\text { Behavior }\end{array}$ & - & - & Perhatikan! (1) & - \\
\hline 11. & $\begin{array}{c}\text { Criticizes } \\
\text { Student } \\
\text { Responses }\end{array}$ & - & Hem, really? (1) & $\begin{array}{l}\text { Four sentences, } \\
\text { are you sure? (1) }\end{array}$ & - \\
\hline
\end{tabular}

Table 1 show that asking question was the high frequent of teacher talk category used based on Foreign Language Interaction (FLINT) model produced by English teacher in $1^{\text {st }}$ until $4^{\text {th }}$ meeting. It meant that teacher tended to used indirect influence rather than direct influence.

It can be concluded that both teachers had the same two categories in the highest frequency, asking question in first place, giving information in second place, and giving direction in third place.

\section{Discussion}

Regarding the result of video recording in previous part, the researcher concluded that the research findings were divided into two parts. Firstly, there were three categories of teacher talk that often used from categories of teacher talk used by both the teacher was asking the question, giving information, and followed by giving direction. Out of eleven categories of teacher talk that used, correcting without rejection and criticizes student behavior were rarely used by both the teacher. The researcher would like to give the clear explanation such as.

First, Asking Question was the most categories used by teacher in the process of interaction in the classroom. Most of the students talk begin when the teacher ask question to them. Teacher distinguished not only by the exclamation mark but also when teacher is waiting for students' response which indicates that the teacher is giving a question.

Teacher in classroom employed different types of question to make teaching effective and enhance students' proficiency in the target language. As it has been explained by Long and Sato (cited in Ndun, 2015), have classify teachers' questions as referential and display questions. Referential question was type of questions requesting new information or answers that teacher did not known, and students answer tha questions in order to give teacher information. For example in first meeting, teacher asked "What else that stuff, this is present perfect tense?" and student answer "Verb III". 
Furthermore, display questions refer to ones requesting information or answers that already known to the teacher. In addition, display question was designed to elicit or display particular structures, elicit short, simple and low-level answers.For example in third meeting, teacher asked "What is the purpose of recount text?" and student answer "Recount text is about menceritakan kembali cerita yang sudah pernah terjadi". Based on this example, the teacher tried to ensure students to understand recount text and asked the students to elaborate instructions which were in line with Brown's study (2001) that showed Asking Question is one of a way to stimulate students in speaking up their thought.

Second, giving information was one of the most categories used by the teacher in the process of interaction in the classroom. Teachers gave some information to students that related to the materials, and they gave information during teachinglearning process, in order to the students had new information or knowledge from the teacher. For example in third meeting, teacher said "Kalo bahasa Inggris stress kata itu penting ya. Itali stress kata itce, italian ta... talien. Itelien baru talien Itali. Germany...jer. Beda ya itu." Teacher delivers the material and then gave explantion about the material. Teacher as facilitator was one of the interative teacher in classroom (Brown, 2000).

Third, giving direction was seldom used by teacher in the process of interaction in the classroom. Teacher has to give directions, commands, or order to which a student was expected to comply with took a quite large proportion. It happened when she/he asked student to do assignments or tasks and answer the questions. For example "You can open your textbook!" The finding of this category was significantly different with Nurmasittah's (2010, p. 87). In other hand, she points out that giving direction was one of the least types used in the classroom interaction which meant that the teacher used a little time to control the students during the teaching and learning process.

Fourth, correcting without rejection and criticizes student behavior was rare used by the teacher in the process of interaction in the classroom. Correcting without rejection occurred when teacher pointed a student and asked them to give their opinions toward the topic discussed, and then teacher corrected the mistake immediately by saying the right pronounciation. For example in meeting 3, teacher corrected the students' pronounciation, "Italian. Italian is that you was pronounce is from Itce.. Itcelien not ita..lian."When students made mistakes, the teacher would 
correct students in a better way. It means that the teacher did not judge them directly but guides them until they could pronounce it correctly.

Beside, criticizes student behavior was rarely used by the teacher during the process of interaction in the classroom. Teacher threw the critics toward unfocused and noisy students during teaching-learning process. Teacher also reprimanded to students, because it might disturb other students so they lost their concentration and they could not follow the learning. In fact, the voice of students made the atmosphere in the classroom crowded during teaching-learning process so that the teacher needed to criticism them to keep silent.

Secondly, the highest frequency of teacher talk's used by the teachers was asking question. It was used by Teacher A around $65.9 \%$, while it was used by teacher $B$ around $51.1 \%$ but asking question in all meetings around 55 . 6\%. It meant that the teachers necessarily ask questions to encourage the students so they were able to spoke up. Asking question toward the expected answer was highly anticipated on students understanding and arousing their knowledge, also controlling the class. It proven by high percentages that showed the teachers took large proportion of doing it. It could be said that both teachers in order to get students responses in conducting classroom interaction during teaching learning process.

To know the gap, this research was compared to other similar studies. Aisyah (2016) found out that during interaction, the teacher dominate the interaction in teaching and learning process by applying several teacher talk categories such as asking question, followed by lecturing and giving direction. However, this research used FIACS as research theory. In addition, the research that was conducted by Villy (2018) showed that the categories mostly applied were asking question, followed giving direction and using ideas of students. She used FLINT as research theory. Meanwhile Rais (2018) found out that giving information, followed by asking question, and praising and encouraging were the mostly applied by the teacher.

Describing upon explanation above, it can be concluded that both teachers realized the function of teacher talk and they concluded the teacher talk in their classroom interaction in purpose. They realized the role of each category of teacher talk and utilized it well in facilitating the learning process.

\section{Conclusion and Suggestion}


Based on the result of the data analysis, the conclusion of the research results are; 1) both the teacher who taught in tenth-grade at SMA Negeri 5 Kota Bengkulu used all categories of teacher talk based on FLINT theory, although there were three categories often used by the teacher namely asking question, followed by giving information and giving direction. 2) The high frequency of teacher talk used by the teacher during classroom interaction based on FLINT theory was asking question around $55.6 \%$.

Based on the results of the research, the researcher gives some suggestions for the teachers and further researcher. For the teacher the researcher suggests in teaching and learning process the teacher should have creative innovation to manage the classroom and force the students more active in share ideas and ask a question and try using English to interact with the teacher and also other students.

For the other researcher, it is expected that the result of this research could be used as an additional reference and to utilize different theories to analyze teacher talk for the next research. It is good to explore more about the impacts of teacher talk itself.

\section{References}

Afriyanto, H., Harahap, A.,\& Azwandi, A. (2017). An analysis of interactional pattern between teacher and student in SMAN 1 Curup Kota. Journal of Applied linguistic and literature, 2(1): 1-14.

Aisyah, N. (2016). An analysis of teachers' talk in an EFL Classroom. Journal of English and Education, 4(2): 63-79.

Alharbi, A. H. (2015). Improving students' English speaking proficiency in Saudi public schools. International Journal of Instruction, 8(1).

Azizah, N. (2019). Teacher's talk and student's talk in classroom interaction of the tenth Grade of MAN 1 Surakarta in Academic Year 2017/2018. Surakarta: State Islamic Institute of Surakarta.

Bogdao, R. C., \& Biklen, S. K. (2003). Qualitative research for education.

Brown, H. Douglas. (2000). Teaching by principles: An interactive approach to language pedagogy. 2nd Edition. New York: Person Education.

Brown, H. Douglas. (2001). Teaching by principles: An interactive approach to language pedagogy. New York: Person Education. 
Cresswell, J. (2008). Education research: Planning, conducting, and evaluating quantitative and qualitative research. New Jersey: Pearson.

Damhuis, R. \& de Blauw, A. (2008). High quality interaction in the classroom: A focus for professional learning. L 1 educational studies in language and literature, 8 (4): 10712.

Darigan, M. (2004). Classroom interaction and communication strategies in learning English as a foreign language. Ljubljana: ELOPE.

Flander, N. (1970). Analysis teaching behavior. Reading, MA: Addison-Wesley.

Gharbavi, A. \& Iravani, H. (2014). Is teacher talk pernicious to students? a discourse analysis of teacher talk. Procedia-Social and Behavioral Sciences, 98: 552-561.

Gebhard, J. G. (2006). Teaching english as foreign language or second anguage: A teacher Self-development \& methodology guide. Universuty of Michigan Press.

Goronga, P. (2013). The nature and quality of classroom verbal interaction: Implications for primary school teacher in Zimbabwe. Part-II: Social Science and Humanities, 431-444.

Hai, S. K. \& Bee, L. S. (2006). Effectiveness of interaction analysis feedback on the vebal behavior of primary school mathematic teacher. Jurnal Pendidik dan Pendidikan, Jil. 21: 115-128.

Harahap, A. \& Emzir, E. (2015). Teacher-students discourse in English teaching at high school (Classroom discourse analysis). International Journal of Language Education and Culture Review, Vol. 1 (2), 2015, 11 - 26

Julana, N. F. 2018. The pattern of classroom interaction in English speaking course. Banda Aceh: Ar-Raniry State Islamic University Darussalam.

Kiranthi, D. (2019). An analysis of teacher-students classroom verbal interaction at the eleventh grade students of MA Alislam Jamsaren in the academic year 2019/2020. Surakarta: The State Islamic Institute of Surakarta.

Kumpulainen, K. (2009). Investigating classroom interaction. Methodologies in action. Rotterdam, Taipe: Sense Publishers.

Lasac. (2011). Classroom interaction analysis on teacher-students mathematical at attitude and achievment. Master in Arts of Mathematics College of Science.

Makhamirudin, A. A. (2015). Improving teacher talk to enhance teacher-students interaction (An action research at SMPN 1 Slawi). Semarang: Semarang State University. 
Moskowitz, G \& Haiman, J. L. (1976). Success strategies of inner-city teacher. A yearlong study. Journal of Education Research

Ndun, L. N. (2015). Teacher question in the junior high school English classroom. Yogyakarta: Sanata Dharma University

Nuri, T. D. (2019). Teacher talk in English classroom Interaction: A case study at SMA Muhammadiyah 18 Sunggal. Medan: University of Muhammadiyah Sumatera Utara.

Nurmasithah, S. (2010). A study of classroom interaction characteristics in a Geography class conducted in English: The case at year ten of an immersion class in SMAN 2 Semarang. Postgraduate Schoo. Semarang, Indonesia: Diponegoro University.

Ogunleye. (2010). Dimension of teacher's verbal interaction in the classroom: A comparative English Study. Occasional papers in education and lifelong Learning: an international journal, 4(1-2): 131-153.

Preston, L. R. (2010). A glimpse into classroom interaction. Barcelona: Unpublished master's Disseration.

Putri, D. S. (2015). The analysis of teacher talk and the characteristic of classroom interaction in English as a foreign language classroom. Journal of English and Education, 3(2), 16-27.

Radford, L. (201 1). Book review: classroom interaction: why is it good really? Educational studies in mathematics.

Rais, M. F. (2018). Teacher talk in speaking course: a descriptive study at English department in UIN Ar-Raniry. Banda Aceh: Ar-Raniry State Islamic University Darussalam.

Ribas, M. S. (2010). The effect of teacher talk on student's oral. Final Master Dessertation. $U A B$.

Sangmeister, K. M. (2008). "If you hear my voice, do the hula": the nature of teacher talk during classroom routine in intermideate classroom in an exemplary urban school. Ann Arbor: Proquest LLC.

Septiningtyas, M. (2016). A study of classroom interaction in teaching English to young learner (TEYL) classroom using flanders' interaction analysis system. Yogyakarta: Sanata Dharma University.

Sudijono, A. (2009). Pengantar statistik pendidikan. Jakarta: Rajawali Pers.

Tuan, N. H., \& Mai, T. N. (2015). Factors affecting students' speaking performance at le thanh high school. Asian Journal of Education Research, 3(2), 8-23. 
Villy, N. A. (2018). Teacher talk in classroom interaction in teaching speaking for the first grade students at SMA Negeri 20 Medan. Medan: State University of Medan.

Walsh, S. (2002). Talking the talk of the TESOL classroom. ELT Journal, 60/2: 133-4 1.

Wang, H. (2014). The analysis of tacher talk in "Learner-Centered" teaching mode. International Journal of Social, Behavioral, Education, Economic, Bussiness, and Industrial Engineering, 8(4).

Wardhana, A. (2016). An analysis of the teacher talk in the classroom interaction (a descriptive qualitative study at the second grade of SMAN 1 Sukamaju). Darussalam, Banda Aceh: Syah Kuala University.

Warsiti, W. (2017). A study on classroom interaction at the eighth grade of SMP AI Islam Kartasura. Surakarta: The State Islamic Institute of Surakarta.

Yanfen, L \& Yuqin, Z. (2010). A study of teacher talk in interactions in English classes. Chinese Journal of Applied Linguistics (Bimonthly), 33(2), 76-86. 